\title{
THE DOOM OF EARLY AFRICAN HISTORY?
}

\section{Jan Vansina \\ University of Wisconsin-Madison}

In the initial paragraph of a set of book reviews dealing with a sixteenthcentury relation and a map by Ptolemy, Michel Doortmont informs us casually that:

The ancient and early modern [sic] history of Africa is no longer a very popular topic with mainstream [sic] African historians. Sources are scarce, often difficult to interpret and in many cases the results of research are disappointing [sic]: no wonder that most serious scholars [sic] leave the earlier periods alone. This is unfortunate, however, as the lack of serious and methodical scholarship [sic] on these periods gives fuel to the view of Africa as a mysterious and highly exotic continent still held by many outside the academic community.

Quite a statement! How arrogant and how gratuitously insulting to all those who do study "ancient and early modern history." If Doortmont were alone in his views, one might just as well ignore this as an example of regretable idiosyncrasy. But the cavalier way in which he delivers his opinion suggests that he merely voices a truism, i.e., an opinion that he thinks is shared by most of his colleagues. Moreover, such a statement will surely frighten budding scholars away, which in itself is a good reason not to let such a sweeping condemnation of the study of earlier African history pass without comment.

Four main claims are made here: (a) a dichotomy and a contrast exists between those who who study the more remote past and those who study the recent past; (b) the first group is small and out of the mainstream; (c) its research yields disappointing results; (d) its scholarship lacks seriousness and method-with (b) and (c) of course in implicit contrast to the second group.

As to the constitution of these groups, one may wonder what Doortmont means by "ancient and early modern history" and whom he includes in that category. Because of his mention of "few" and "mainstream" he apparently excludes Egyptologists, Classicists, historians of northern Africa, and perhaps even Ethiopianists or Islamicists, and he certainly excludes archeologists, historical anthropologists, and linguists - as if they had nothing to contribute to the study of Africa's early history. His "African historians" seem to be historians of tropical Africa, and then only those who base their research on written documents or use oral data. His dichotomy also lacks a precise boundary between the two groups. His expression, "early modern" apparently derives from the history curriculum in many continental European countries. If so, the period ends with the French Revolution or-more relevant to tropical Africa - the Industrial Revolution. Yet from his comment about

History in Africa 24 (1997), 337-343. 
sources, one suspects that he is actually not referring to absolute chronology, but contrasts scholars who have abundant written data at their disposal with those who do not.

True, there clearly does exist a dichotomy between two groups of historians who work in quite different ways, even with written sources. Where sources are abundant most scholars are content to establish the credibility of assertions made in one document by checking these with assertions made in other documents without engaging in a close scrutiny of their sources. ${ }^{2}$ Conversely, when documents are rare, each one is as thoroughly scrutinized as possible by using the rules of evidence to their full extent and by placing every document in the widest known context of period and place. Moreover, where written sources are rare, one uses other sources-whether oral, archeological, biological, or linguistic. This sort of history is thus pursued in an interdisciplinary context to the extent that the exact academic label of each scholar may be less relevant than it is for the first group.

It is also correct to state that the number of academic historians who study earlier times in tropical Africa is relatively small compared to the number of those who study the well-documented parts of its recent history. But they are not "few" in any absolute sense, as even a cursory perusal of History in Africa or Journal of African History shows. The number of academic historians in the "early" set certainly lies well over one hundred. The belief (Doortmont's "no longer") that more historians of Africa used to be engaged in this pursuit than there are now is unfounded. This view probably derives from the circumstance that some well-known scholars have switched from an interest in earlier periods to later ones whereas far fewer have made the reverse journey. In fact the number of historians in the "early" set has also grown over time, albeit at a slow rate compared to the numbers of recruits to the "modern" set. Lack of preparation in graduate school for this kind of research, the seemingly daunting complexities of the research itself, and prejudice on the part of many thesis advisers explains why the number of new recruits for early African history remains small.

Historians of various stripes belong to this "early" set. Some lay a solid foundation for later historical interpretation by preparing text editions, an activity which often requires the greatest erudition and is quite timeconsuming, even if many historians of the near present have little regard for this sort of work. These simply have no idea of the amount of research and the ingenuity which goes into this sort of activity, nor of its importance for the evaluation of sources. ${ }^{3}$ Others publish interpretations based on the close critical study of the written texts, a job which inter alia requires a thorough knowledge of by-now dead languages such as ancient Greek or Latin, or archaic language forms as in medieval Arabic or European languages from the fifteenth century onwards.

Still others are knowledgeable in one or more disciplines besides history, such as historical linguistics, archeology, cultural and social anthropology, or even biology, and they use this expertise in their reconstructions. ${ }^{4}$ Besides all these historians, one finds scholars in other disciplines who also study issues 
in early African history and interact with historians proper. This group includes archeologists (so-called "historical," as well as others), a growing number of anthropologists, some art historians, and the occasional linguist, biologist, or climatologist. Together with the academic historians these scholars participate in a common endeavor and all of them form a single intellectual community. It is therefore an error to restrict the number of scholars working on earlier African history to academic historians only. Counting should include all the parties active in the research. Hence the "few" may well number several hundred, even when one omits those who study northern or northeastern Africa-and who should in fact be included.

Are all these people out of the "mainstream?" But then is not any "mainstream" in the eye of the beholder? Certainly the term is relative: it presupposes a bounded community and a certain common activity or substance of reseach. For example, if we go by the sheer numbers of all historians in the United States, then the "mainstream" undoubtedly studies the history of the United States, and all historians of Africa are marginal eccentrics. In fact Doortmont clearly refers to a group encompassing all academic historians of Africa, but obviously not other scholars who study issues pertaining to the history of Africa. He apparently uses the expression merely to contrast the many scholars who use abundant written material with the few who do not.

But the strength of a herd instinct surely is neither a guarantee nor a measure of the quality of research done. Perhaps, however, his "mainstream" also refers to particular approaches or interests, say a preference for a certain form of social history as opposed to other kinds of history, in which case the preference for one goal rather than another simply reflects fashion or prejudice. Certainly it is not self-evident that a preferred approach or goal is better than others. At any rate, it is useless to consider this charge further as long as one does not know what this mysterious "mainstream" refers to.

For Doortmont most, or indeed all, historians of earlier periods are neither "serious" (mentioned twice, for emphasis) nor methodical. He does not just generalize from one case, the author of the works he reviews; indeed, at the end of this same first paragraph that person is said to practice "serious scholarship," albeit not methodically. How anyone could claim this in the face of existing historiography is beyond me. Is not one of its distinctive features its great care and explicit attention to historical method and criticism, all the more so because the scarcity of its sources and the pitfalls attending their interpretation compels it to use this approach? Thus the only in-depth discussion of written documents for whatever period as sources for the history of Africa still remains European Sources for Sub-Saharan Africa Before 1900: Use and Abuse ${ }^{5}$ while perusal of History in Africa also makes abundantly clear how concerned these historians are about issues of method.

Are those who utter such a charge not familiar with the literature? Or is the charge perhaps derived from the fact that this literature draws attention to existing flawed practices, whereas much of the historiography about recent African history does not? Unfortunately, methodological flaws can be found in the work of historians whatever their chosen period of interest, and indeed 
perhaps less rather than more, among those who deal with scarce sources because the fewer the sources or the harder they are to find, the more they are treasured and scrutinized.

We are told that it is not worthwhile doing research on early periods of African history because the results are "disappointing," another loaded term. Literally, it means that the results do not come up to expectations. Research that merely serves to confirm a priori expectations is of less, rather than more, value than research which leads to unexpected results and hence increases knowledge more, or at least indicates deadends not worth exploring.

One suspects, however, that Doortmont uses the word to signify that one learns little or nothing new from the results. That is always untrue: genuine research is never useless. It always brings something new, even if it rarely leads to the full gratification of expectations. Recently, for instance, I set out to check whether a peculiar late sixteenth-century institution from Angola was really reported much earlier from Saõ Tomé, as had been alleged. ${ }^{6}$ If this were so, the consequences would be of great moment as, among other things, they would affect the accepted basic long-term chronology of inner West Central Africa. But the so-called earlier report was a red herring. It did not exist and hence existing views need not change. So nothing new? No, because we have learned that the allegation was false and, that the historiography about São Tomé still mimics a scenario set forth in the late eighteenth century, so that the situation cries out for further research. Yes, this is less spectacular than a wholesale revision of chronology would have been, yet it is just as important in the collective enterprise of history-making.

Incidentally, "disappointment" also leaves the impression that the scholarly activity by these "few" academic historians, contributes very little to the advancment of knowledge about Africa before 1800 . Not so. Even a cursory comparison of the present state of historical knowledge about Africa before $c a .1800$ with the state of knowledge a generation, or even a decade, ago suffices to demonstrate how much the accumulation of often unspectacular new bits of knowledge has led to a much altered and better informed understanding of this past.?

In the last resort opinions like those voiced by Doortmont can only be attributed to sheer lack of familiarity about both the literature and the kind of tasks which confront historians of earlier times. Doortmont's own review of the three books by Lacroix bears this out. The first work discussed is a translation of the familiar 1591 book by F. Pigafetta and E. Lopes. ${ }^{8}$ Doortmont dismisses it in one paragraph as harmless, if nicely-written, and with some useful explanatory notes. He obviously is unfamiliar with the text and the literature about it. Thus he misses the fact that Lacroix had not seen or used the re-edition of the Dutch text of 1597, which was annotated for obsolete Dutch terms and compared to the original Italian by A. Burssens and which surpasses Lacroix's translation techinally.?

Nor did Doortmond check to see how the earlier translations that Lacroix admittedly consulted inspired him or how he used their annotations. ${ }^{10}$ Their example may have misled Lacroix in more than one instance, so that he 
repeats earlier errors. Although it is well known that the language of the book shows Portuguese influence on the Italian of Pigafetta and that Lopes may even have submitted a Portuguese text to Pigafetta, no one has worried very much about possible misunderstandings between the two authors. ${ }^{11}$ And yet there exists at least one clear instance of such a situation-the statement (in the Italian original and in the later translations) that one could buy a tusk for any old ship's nail in Loango, whereas the presumably underlying Portuguese "prego" referred both to "nail" and to, "anchor" and in this case must be understood as the latter. ${ }^{12}$

Lacroix's second work is a historico-geographical analysis of the two maps of Africa in Pigafetta/Lopes with the aim of showing that Africans in Kongo at that time knew the geography of practically the whole interior of the continent. ${ }^{13}$ Doortmont correctly criticizes the confusion between hypothesis and proof. But he shows his unfamiliarity with the literature by complaining about the book's "endless" list of geographic locations, each accompanied by the relevant literature and the author's own preferences, something which is standard practice in that literature.

Once again though, Doortmont does not address some of the fundamental issues and hence misses crucial weaknesses. First, the whole argument hinges on who the author of the general map of Africa was: Lopes, as Lacroix claims, or Pigafetta as all other scholars claim? Given the map's construction in the Italian rather than the Portuguese mapmaking tradition, there can be little doubt that Pigafetta, not Lopes, constructed it. At most Lopes provided a sketch of Kongo and vicinity but certainly no more: he was a trader, not a geographer and a cartographer like Pigafetta. Hence, outside of the area of Kongo itself, none of the items on the general map of Africa can be linked to any Kongo informant, which vitiates the thesis that sixteenth-century Kongo people had an astonishing knowledge of Africa's interior. A second crucial flaw, the anachronism of Lacroix's penchant for finding etymologies for most of the place names in present-day African languages even when such names (e.g., \#2: Agysimba) stem in fact from Ptolemy is also overlooked. Once again Doortmont's review remains inadequate.

Lacroix's third work under review discusses the map of Africa by Ptolemy and argues that most of Africa was then known to geographers. ${ }^{14}$ Faced with this topic, the reviewer is obviously out of his depth. He pays no attention to manuscript traditions nor to the edition(s) and languages Lacroix used. He does not even notice that Lacroix relied on Mercator's 1578 rendering of Ptolemy's maps and that he does not seem to have compared these to any manuscript. ${ }^{15}$ He does not refer to Lacroix's treatment of various features on the maps (e.g., overlaps between several maps, duplications of place names, interpretations of flumina)

Doortmont does not notice that, while Lacroix made use of scholarly commentaries about place names, he did not check Ptolemy against contemporary or older descriptions of Africa. Thus in his chapter about the East Coast, Lacroix cites many older commentators about places mentioned in the Periplus of the Erythraean Sea but uses none of the text editions or 
standard translations. Lacroix clearly has not read this book. It is therefore evident that his analysis of Ptolemy must remain very superficial. ${ }^{16}$ And once again the reviewer neglects to point out how anachronistic it is to derive etymologies from present languages to explain place names used ca.100 $\mathrm{AD}$ (such as to claim that the placename Rhapta stems from Kiswahili "Arabu," at a time when the Swahili language did not exist!). On the other hand, Lacroix has some Greek and clearly has mastered Latin. Some of his specific suggestions might have merit, but only a specialized classicist would be able to spot these. That is an important feature of the work, but one which the reviewer has overlooked.

One cannot but conclude that Doortmont simply did not apply most rules of historical evidence, nor a knowledge of the relevant literature to evaluate these works by Lacroix. Inevitably, it makes one wonder how many others in his "mainstream" overlook the elementary requirements to evaluate documentary evidence, let alone non-written evidence. It is a deeply disturbing thought.

How could it be that professional historians are not thoroughly familiar with such basic rules of evidence and do not apply them almost as a matter of reflex? A rhetorical question this, because as teachers we know the why and how. Students in history, even graduate students, are no longer systematically trained in the use of rules of evidence. Most, for instance, have never had to read, transcribe, and describe a manuscript, even as an exercise, or to check its authenticity and its sources, assess its originality, edit even one page of text, establish authorship, establish place and time of composition, or evaluate a translation, all of which is deemed unnecessary drudgery. After all, does not the student interested in the recent past dispose of such masses of written data that one need only check a corpus for its internal consistency and go by that?

Yet, as the celebrated story of Hitler's forged diaries - for instanceshows, it is not sufficient even for the most eminent practitioners. Students interested in earlier times are somehow expected to be already proficient in the application of the rules of evidence before they choose to specialize in African history. Moreover, it is often thought that text editions or even translations exist for all the sources they need, so that they can use these without further ado, irrespective of their quality. Yet scholarly text editions are rather rare and carefully annotated translations even rarer. ${ }^{17}$ It very often happens that there are no text editions, so that students are left to struggle with manuscripts, and have to rediscover rules of evidence for themselves.

The dichotomy which Doortmont highlights indicates a worrisome flaw in the training of historians. In doing away with the formal and practical study of the rules of evidence, history departments have overlooked that training in this skill sharpens one's ability to evaluate evidence critically, an ability that is just as necessary to confront masses of recent sources as it is to cope with the rarer documentation from earlier times. These rules must also be applied to the evaluation of any work of historiography, even before one considers their style, historical imagination, and intellectual brilliance. In the end, it is primarily a thorough grounding in historical method that distinguishes 
historians from others, whether social scientists, humanists, or just writers of fiction. Surely the time has come to reinstate the historical method and its rules of evidence to a central position in the training of historians.

\section{Notes}

1. M. R. Doortmont, "Texts without Context," JAH 37 (1996), 490-92. This reviews three works by W.G.F. Lacroix.

2. See the comments in "An Interview with Henri Brunschwig" in Pilgrims to the Past, ed. P. Blussé et al. (Leiden, 1996), 51-52, on the value of "premature books," written before all the available evidence could be consulted.

3. In their hurry many of the earliest academic historians built up a history of Africa that took whatever printed material they could find at face value with sorry results. See Jan Vansina, Living with Africa (Madison, 1994), 134-36. Cavalier attitudes towards written sources are still all too common.

4. E.g., The journal Sprache und Geschichte in Afrika from 1979; David L. Schoenbrun, "We are What We Eat: Ancient Agriculture Between the Great Lakes," JAH 34 (1993), 1-31 on words and things; Stephan Bühnen, "Place Names as an Historical Source: An Introduction With Examples from Southern Senegambia and Germany," HA 19 (1992), 45-101; Christopher Ehret and Merrick Posnansky, eds., The Archaeological and Linguistic Reconstruction of African History (Berkeley, 1982); Peter R. Schmidt, Historical Archaeology (Westport, 1978).

5. Edited by Beatrix Heintze and Adam Jones and published as volume 33 (1987) of Paideuma.

6. Jan Vansina, "Quilombos on São Tomé, or In Search of Original Sources," HA 23 (1996), 453-59.

7. A discussion of the most notable specific advances would be too long and out of place here. Some sense of recent advances can already be gained by a look at recent onevolume textbooks such as John Iliffe, Africans: The History of a Continent (Cambridge, 1995), or P.D. Curtin et al. African History (2d. ed.: New York, 1995), compared with the first edition published in 1978.

8. W.G.F. Lacroix, Beschrijving van het Koninkrijk Kongo en van de omliggende gebieden (Delft, 1992).

9. A. Burssens, "De Beschryvinghe van't Groot ende Vermaert Coninckrijck van Congo (1596)," Kongo Overzee 2 (1941/42), 1-86, 113-203.

10. He was influenced especially by Willy Bal, Description du Royaume de Congo et des Contrées Environnantes (2d. ed.: Louvain, 1965).

11. Ibid., xx, xxxiv, note 62.

12. Book 1: DX, paragraph 4. In Lacroix's edition, p. 57.

13. Lacroix, Het binnenland van Afrika in de zestiende eeuw: Een historischgeografische analyse van Duarte Lopes kaart van Afrika (Delft, 1992).

14. Lacroix, Afrika in de oudheid (Delft, 1993).

15. Ibid., 11. According to his notes Lacroix used the text of EL. Stevenson, Geography of Claudius Ptolemy (New York 1932).

16. The recent transiation by G.W.B. Huntingford for the Hakluyt Society (London, 1980), does not allow one to check the original. Hence Africanists should use Lionel Casson, ed. and trans., The Periplus Maris Erythraei (Princeton 1989).

17. The guide for West Africa, J.D. Fage, Original Sources for Precolonial Western Africa Published in European Languages (2d. ed.: Madison, 1994), is invaluable in this regard. 